\title{
Cohort Differences in Swedish Union Membership 1956-2019 and the Role of Individualization'
}

I Erik Vestin ${ }^{2}$

Independent researcher, Sweden

I Patrik Vulkan

Senior Lecturer, Department of Sociology and Work Science, University of Gothenburg, Sweden

\begin{abstract}
Discussions of the role of cohort differences have long been part of academic research on union membership, with a central hypothesis being that the general decline in unionization is caused by changes toward more individualistic values in the younger generations. However, the short time span of most studies makes it uncertain if they can separate cohort effects from age effects. Using survey data going back to 1956, we test the individualization hypothesis. Our main result is that later Swedish cohorts are indeed less prone to join unions. In particular, the differences between cohorts born before and after ca 1970 are striking. We also provide evidence that the erosion in union membership in Sweden is not related to changes toward more individualistic values in later cohorts, or even to more negative views of unions per se.
\end{abstract}

\section{KEYWORDS}

Cohort analysis / individualization / attitudes / life-cycle development / Sweden / union membership / Nordic model

\section{Introduction}

igh unionization rates are an integral part of the Nordic labor market model in that a well-organized labor force (as well as the other social partners) is considered a precondition for the possibility to combine liberal, flexible government regulations of the labor market and economic growth with guarantees that prosperity will be shared broadly in society. While many researchers have reported negative trends regarding the latter goal in the Nordic countries, as well as most of the Western world, the Nordic Model is far from dismantled, and unionization is still comparatively high in these countries, Sweden included (Jensen 2017; Kjellberg 2019a). Analyses of the prospects for union membership in Sweden are thus still relevant for assessments of the long-term viability of this labor market model.

The level of unionization in the Nordic countries is commonly explained by looking at either structural, institutional or micro-oriented factors, or a combination of these (Jensen 2017; Palm 2017). On some factors, there is near consensus that they help improve the level of unionization, such as centralized union organizations, workplace representation, and Ghent-system unemployment funds, ${ }^{1}$ while some factors such as shrinking public sectors, a fall in firm size and a rise in atypical employment have a

\footnotetext{
${ }^{1}$ You can find this text and its DOI at https://tidsskrift.dk/njwls/index.

${ }^{2}$ Corresponding author: Erik Vestin. E-mail: vestin.erik@gmail.com.
} 
detrimental effect on union density (Palm 2017; Schnabel 2013). Kjellberg (2020) discusses the recent decline in union membership in Sweden from an organizational perspective, in relation to structural and institutional changes in the Swedish labor market, stressing the structural transformation of the economy, migration, and the abolishment of the deductibility of membership fees.

Our contribution is to analyze the Swedish development in a cohort perspective, looking to assess the long-term trajectory of union membership and potential signs of erosion from the perspective of the individuals. International research on union membership has discussed cohort effects in relation to two theoretical models. The first is based on the notion of an increasing individualization in society (Beck 1994; Inglehart 1997). These authors argue that several important social trends, including a decline in union membership, are caused by a change towards more individualistic values in the younger generations, away from a more collectivist mindset that supposedly underpinned unions in the early post-war era. So far, however, the connection between this value change and union membership has only rarely been investigated on the individual level (Schnabel 2013, pp. 263-264). The second model is a more general idea that union membership is a habit that has to be acquired at an early age or early stage in one's career; otherwise, one will remain a non-member (Budd 2010; Ebbinghaus et al. 2011; Visser 2019). However, this second model has rarely been tested in such a way as to tell age and cohort effects apart, nor specifically in a Swedish setting, and longitudinal evidence that union membership works this way is scarce.

This article contributes in four ways to the discussion of cohort effects in union membership. First, we add the case of Sweden to the literature, with rich data spanning 64 years, that is, the longest time span ever in a study of union membership using individuallevel data. This makes it possible for us to assess empirically how union membership develops with age by tracking cohorts over a very large part of their work life, rather than putting together relatively small parts of several cohorts through statistical controls. We also validate our new sources by comparing them to earlier ones (Kjellberg 2019b). Second, our main result is that later Swedish cohorts are indeed less prone to join unions. In particular, the differences between cohorts born before and after ca 1970 are striking. Third, our cohort analysis shows that every cohort since at least the 1950s goes through a rise in union membership in their 20s, reaches a plateau in their early 30 s, and begins a slow decline around their 60s. Fourth, we address the individualization theory of union membership decline. The analysis also leads us to suggest that the relationship between union membership and the lifespan of a cohort is best modelled using a negative inversion transformation, rather than the quadratic transformation that has been debated earlier. While we do not provide a full-scale analysis of the causes of the cohort differences, we offer evidence that they are not related to changes towards more individualistic values in later cohorts, or even to more negative views of unions per se. In our discussion, we briefly outline where we think one should look for the correct explanations. We close the article with a discussion of the prospects for the Nordic Model in Sweden in the light of these results, and where further research on union membership should put its focus.

\section{Previous research}

Research on cohort effects on union density often suffers from short periods of study, with results often being either ambiguous or imputed as the effects of age and cohort

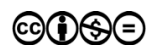


cannot be properly distinguished. Nevertheless, international research gives some indications on the cohort effect on union density, especially with regard to the relationship between union membership for different ages/cohorts.

In a seminal paper, Blanchflower (2007) states that the probability of being unionized follows an inverted U-shape with regard to age in 34 of the 38 countries tested, Denmark, Finland, Norway and Sweden included. The peak of Swedish union density is at ages 45 and 47, based on data covering 2000-2002 and 2002-2004, respectively. Cohort effects are only tested for in the UK and the USA, where effects are found but not to the extent that the inverted U-shape in age disappears. Using European Social Survey (ESS) data from 2002 to 2003 in a cross-sectional multilevel analysis for EU countries, Ebbinghaus et al. (2011) likewise find a concave relationship with union membership and age with the likelihood of union membership increasing up to the age of 54, after which it declines. Testing for the inverted U-shape for age using cross-sectional ESS data for 2002-2003, Schnabel and Wagner (2007) find statistically significant support in Denmark, Finland, Poland, and Sweden but not in any of the other 14 EU countries, while also controlling for personal and workplace characteristics, attitudes, and social factors. The causes of this relationship are left uninvestigated, partly due to the limitations of the data, but the authors speculate that they may result from different needs for union membership for young and old workers, free-riding behavior, and structural as well as cohort effects.

However, Schnabel and Wagner $(2008,2012)$ find little support for Blanchflower's inverted U-shape when testing with a longer longitudinal dataset, using West German data for the period 1980-2006. Applying cohort analysis, the authors find that both intra-cohort change and cohort replacement effects are of almost equal importance in explaining the fall of union density (Schnabel \& Wagner 2008), and they question the methodological approach by Blanchflower (Schnabel \& Wagner 2012). Regarding the causes behind the generational effects, Schnabel and Wagner (2008) suggest changes in education, rising unemployment, the rise of white-collar, service sector and atypical employment, as well as growing individualization as possible candidates, but ultimately provide little empirical evidence to establish any actual causes.

Using data from 1991 to 2000 for Finnish employees, Böckerman and Uusitalo (2006) find that union density quickly increases up to the age of 30 , then stays relatively constant until close to retirement age; the results thus reject the U-shaped form. ${ }^{2}$ A decline in union density during the 1990 s can mainly be attributed to a decrease in union membership among the cohorts born after the early 1960s, who are $20 \%$ less likely to be union members compared with the cohorts born immediately after the Second World War, although the age, time and cohort effects cannot be unambiguously identified (Böckerman \& Uusitalo 2006). Visser (2019) studies union density for workers in industrialized countries aged 16-24 and 55-64 years using data from 2014 and finds that older workers are 4.3 times more unionized than younger workers. Visser (2019) and Schnabel (2013) both stress the challenge inherent in the cohort effects facing unions, as earlier cohorts are both larger and have higher levels of union density compared with later cohorts with lower union density, as well as being smaller, resulting in fewer members and shrinking union organizations.

A related component in the trend of falling union density is the observation that there seems to be an age after which people rarely join unions anymore. Visser (2019) 
finds that workers who have not joined a union before the age of 30 or 35 are unlikely to do so later, which indicates a trend of a growing proportion of workers who never join a union. Following US individuals aged 15-16 in 1979 up to 2004, Budd (2010) finds that among those who joined and stayed in a union, more than $70 \%$ had first joined by the age of 25 and $96 \%$ by the age of 40 . Analyzing Dutch workers in the early 1990s, Visser (2002) finds that they tend to join unions when they are young, usually when they have gained their first stable job and begun establishing a family. Workers join a union within the first few years following their entry into the labor market, or they do not. Likewise, those who stay in the same job for five years and have not already joined are extremely unlikely to join. Workers with a less stable attachment to the labor market are less likely to join a union (Visser 2002). ${ }^{3}$ Ebbinghaus et al. (2011) also stress the life-course dimension, with an apprentice or trainee who is offered a permanent position being the most likely to join a union, especially if the workplace has union representation, while recruitment problems occur later in life and the propensity to leave the union grows near the end of the working life. Regarding the explanations for this pattern, differences in attitudes to unions between cohorts are mentioned, as are labor markets in which there is a high prevalence of youth unemployment, atypical work and little training, making young people unlikely to commit long term to unions. In contrast, older workers are more interested in staying in their current job or with the same employer. Unions might also have less interest in focusing on younger cohorts as they are relatively smaller, while younger workers might feel alienated from unions that mainly cater to the interests of older workers (Ebbinghaus et al. 2011).

Although increasingly individualistic attitudes among younger workers as a reason for union decline have been proposed by influential scholars such as Inglehart (1977) and Beck (1994), closer inspection of this hypothesis has been limited. Gomez et al. (2002) found younger workers in Canada to be more in favor of unionization than older workers. Bryson et al. (2005) also noted that a large proportion of union density difference between young and older workers in Canada, the UK, and the USA was due to a lack of unionized jobs rather than a lower desire for unionization.

The most ambitious test of the individualization hypothesis has been conducted with ESS data from 2008 by Kirmanoğlu and Başlevent (2012). They find that testing for basic personal values does not make the correlations between union membership and aspects such as sector, occupation, establishment size, age, or income disappear. However, they still find significant correlations between union membership and basic personal values: personal values expressing individualization have a negative relationship with union membership, while more communal personal values have a positive relationship. Fewer of the basic value scores are significant when testing for the Ghent countries (i.e., Belgium, Denmark, Finland, and Sweden). Kirmanoğlu and Başlevent (2012) comment that personal values are less important when union membership is widespread and common. Nonetheless, their results indicate that changing personal values could be an important factor behind the decline in union membership and that growing individualism could be a challenge to union organization. However, their analysis is based on a single cross-section and does not include interactions between age and personal values. Thus, further research is warranted on whether growth in individualistic values over time can be found among the young, and if this development correlates negatively with union density.

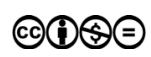




\section{Institutional and structural setting of the Swedish case}

As noted (Høgedahl \& Kongshøj 2017; Jensen 2017; Palm 2017; Schnabel 2013), unionization and union density are commonly explained by structural, institutional or micro-oriented factors, or a combination of these. While we will not delve into the interactions between individualistic attitudes on the one hand, and institutional and structural factors on the other hand, given the long time span of our dataset, we briefly comment on the main institutional and structural factors concerning the unionization in Sweden to situate the development.

The general trend illustrated in Figure 1 traces the growth in union membership in Sweden from the 1960s through the 1980s, with a peak during the 1990s and a noticeable drop during the 2000s. The growth period corresponds with several developments beneficial to unionization: a mostly booming labor market characterized by large industry firms; a growing public sector; structural and institutional reforms allowing for growing female labor force participation; rising unionization among women in both blue- and white-collar work; centralized union organizations and centralized negotiations between the social partners; a Ghent system of unemployment insurance funds; and comprehensive workplace representation of unions. The economic crisis of the 1990s led to a shrinking public sector and a rise in atypical employment, as well as to the growth of a service sector not traditionally unionized to the same degree as industry. During the 1990s, the option of joining an unemployment insurance fund without joining a union gained interest, although not jointly joining both was still rather unusual up until 2007 (Kjellberg 2020).

The decline in union membership in 2007 is noteworthy for the institutional changes of the unemployment funds, especially the sharply increased and differentiated unemployment insurance fund contributions and the abolishment of tax deductions for both unemployment insurance fund contributions and union membership, in effect dramatically increasing membership fees for many with declining membership in both unions and unemployment funds as a result, especially among the young (Høgedahl \& Kongshøj 2017; Kjellberg 2020). Although the role of individualistic attitudes for unionization is the primary focus of our paper, we return to these other aspects in our concluding remarks.

\section{Data and variables}

For our empirical analysis, we use two data sources: the Swedish National Election Studies (SNES) have been conducted as a national random sample of the electorate 18-80 years old in each Swedish national election since 1956. The SOM Survey has been conducted annually in Sweden since 1986, and uses a random sample of the entire Swedish population aged 16-85 years (in the first years, the age span was 16-75 years). As is the case for all surveys, the response rates for these two surveys have been in decline over the years, but are high compared with other contemporary surveys of the same type. The SNES survey for 2014 had a $56 \%$ response rate, including abbreviated interviews (Oleskog Tryggvason \& Hedberg 2015). The 2019 SOM survey had a 50\% net response rate (Falk 2019). The last SNES survey from 2018 has not been included, as it is not yet publicly available. 
The decline in response rates may raise concerns about how representative the data are for the target population. To date, the SNES team has not published any systematic analysis of their non-responses. The SOM Institute, however, has published an extensive report that shows increasing under-representation of the young in the later years (Markstedt 2014). While the same report shows little to no bias in response rates for different education levels, co-workers at the SOM Institute say in personal communication that there are problems hidden by the higher response rate among older people. Since the older cohorts have more people with no secondary education, there is probably still underrepresentation of those with no secondary education in the younger cohorts. Age and cohort are at the center of our study, and education is a common indicator of the strength of a person's labor market position. We believe that validity along these dimensions is important for this study and mitigate the problem by constructing a weighting variable that interacts age with education level. We use population data from Statistics Sweden from 1985 to 2019 to create in total 21 weighting groups, using three education categories (primary, secondary and tertiary), and seven age categories (16-19, 20-24, 25-29, 30-39, $40-49,50-59,60-65)$. We apply this weighting to our analysis of the SOM data, and to the relevant years for the SNES data. Figure 1 shows the time series for the share of union members in the population, for weighted and unweighted data.

The SNES analysis uses the following variables. Union membership: As noted, we use a dichotomous variable, distinguishing between members and non-members. Cohort/ year of birth: We use a question about year of birth as the basis for our cohort and age variables. Labor market activity: We use a dichotomous variable, distinguishing between those who consider themselves active in the labor market (including the unemployed) and those who do not.

The SOM analysis uses the following variables: Union membership, Cohort/year of birth, and Labor market activity are all the same variables as for the SNES surveys. Individualism: In the final part of our analysis, we make use of several attitudinal variables to test the individualization hypothesis. In our operationalization of this, we follow Kirmanoğlu and Başlevent (2012) and Kilburn (2009), and measure individualization as a matter of personal values along four higher-order value types that are at the opposite ends of two value dimensions: openness-to-change versus conservation, and self-enhancement versus self-transcendence. The dimension of openness-tochange versus conservation captures the desire of either individual change or social conservation. The dimension of self-transcendence versus self-enhancement captures the desire of either communal commitments or achieving superior status or influence over others. The value types have also been found to be related to political left-right self-identification (Kilburn 2009; Kirmanoğlu \& Başlevent 2012), with opennessto-change expressing a more left-leaning individualization and self-enhancement a more right-leaning individualization, allowing us to analyze different aspects of individualization. The SOM surveys contain a large set of questions asking: 'How important do you think the following things are for you?', with a five-item response scale: 1 'Very important'; 2 'Fairly important'; 3 'Neither important nor unimportant'; 4 'Not very important'; and 5 'Not important at all'. Note that for our analyses, we have reversed the scale so that higher values mean that something is more important (i.e., $5=$ 'Very important). Table 1 provides an overview of the variables used for operationalization, the value types that make up each dimension and the motivational goals represented by each value type.

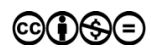


Table I Value types in four dimensions, motivational goals, and variables for operationalization

\begin{tabular}{|c|c|c|}
\hline Dimensions & $\begin{array}{l}\text { Value types (Motivational goal } \\
\text { represented) }\end{array}$ & $\begin{array}{l}\text { Variables used for } \\
\text { operationalization }\end{array}$ \\
\hline \multirow[t]{2}{*}{ Openness-to-change $(\mathrm{O})$} & Stimulation (Excitement, novelty, and challenge in life) & \multirow{2}{*}{$\begin{array}{l}\text { An exciting life, } \\
\text { Freedom, A life full of } \\
\text { pleasure, Self-respect }\end{array}$} \\
\hline & $\begin{array}{l}\text { Self-direction (Independent thought and action, } \\
\text { choosing, creating, exploring) }\end{array}$ & \\
\hline \multirow[t]{3}{*}{ Conservation (C) } & $\begin{array}{l}\text { Tradition (Respect, commitment, and acceptance } \\
\text { of the customs and ideas that traditional culture or } \\
\text { religion provide the self) }\end{array}$ & \multirow{3}{*}{$\begin{array}{l}\text { Wisdom, Justice, } \\
\text { Salvation, Inner } \\
\text { harmony, National } \\
\text { security, A world in } \\
\text { peace }\end{array}$} \\
\hline & $\begin{array}{l}\text { Conformity (Restraint of actions, inclinations, and } \\
\text { impulses likely to upset or harm others and violate } \\
\text { social expectations or norms) }\end{array}$ & \\
\hline & $\begin{array}{l}\text { Security (Safety, harmony, and stability of society, of } \\
\text { relationships, and of self) }\end{array}$ & \\
\hline \multirow[t]{2}{*}{ Self-transcendence (ST) } & $\begin{array}{l}\text { Universalism (Understanding, appreciation, } \\
\text { tolerance, and protection of the welfare of all } \\
\text { people and of nature) }\end{array}$ & \multirow[t]{2}{*}{$\begin{array}{l}\text { Equality, Family safety, } \\
\text { True friendship }\end{array}$} \\
\hline & $\begin{array}{l}\text { Benevolence (Preservation and enhancement } \\
\text { of the welfare of people with whom one is in } \\
\text { frequent personal contact) }\end{array}$ & \\
\hline \multirow[t]{2}{*}{ Self-enhancement (SE) } & $\begin{array}{l}\text { Power (Social status and prestige, control or } \\
\text { dominance over people and resources) }\end{array}$ & \multirow[t]{2}{*}{$\begin{array}{l}\text { Power, Social status, } \\
\text { Wealth, Self-realization }\end{array}$} \\
\hline & $\begin{array}{l}\text { Achievement (Personal success through } \\
\text { demonstrating competence according to social } \\
\text { standards) }\end{array}$ & \\
\hline
\end{tabular}

In the same context, we also use the variable Trust in unions, which is measured by the question 'How much trust do you have in the way that the following groups and institutions carry out their work?' 'The unions' is then one item out of many. Trust is measured on a 5 -point scale of 1 'Very high trust'; 2 'High trust'; 3 'Neither high nor low trust'; 4 'Low trust'; and 5 'Very low trust'. Also in this case, we have reversed the scale so that higher values mean higher trust (i.e., 5 = 'Very high trust). Trust in unions and its relation to trust in other social institutions are an interesting topic in itself. However, the variable plays only a complementary role. Although this item is not a measure of individualism, it should nevertheless serve well as an indicator of whether the decline in union membership is related to changes in the perception of unions.

\section{Comparison of the surveys with other sources}

Before the evidence is presented, we first show how our sources compare with earlier Swedish sources on union membership. Figure 1 shows the time series of the unionization rate for the SNES and SOM surveys, next to the numbers reported in Kjellberg (2019b), based on archival research for the early years, and on the Labor Force Survey (LFS) conducted by Statistics Sweden for the last 34 years. 
Figure I The unionization rate in Sweden, 1956-2019, according to different sources.

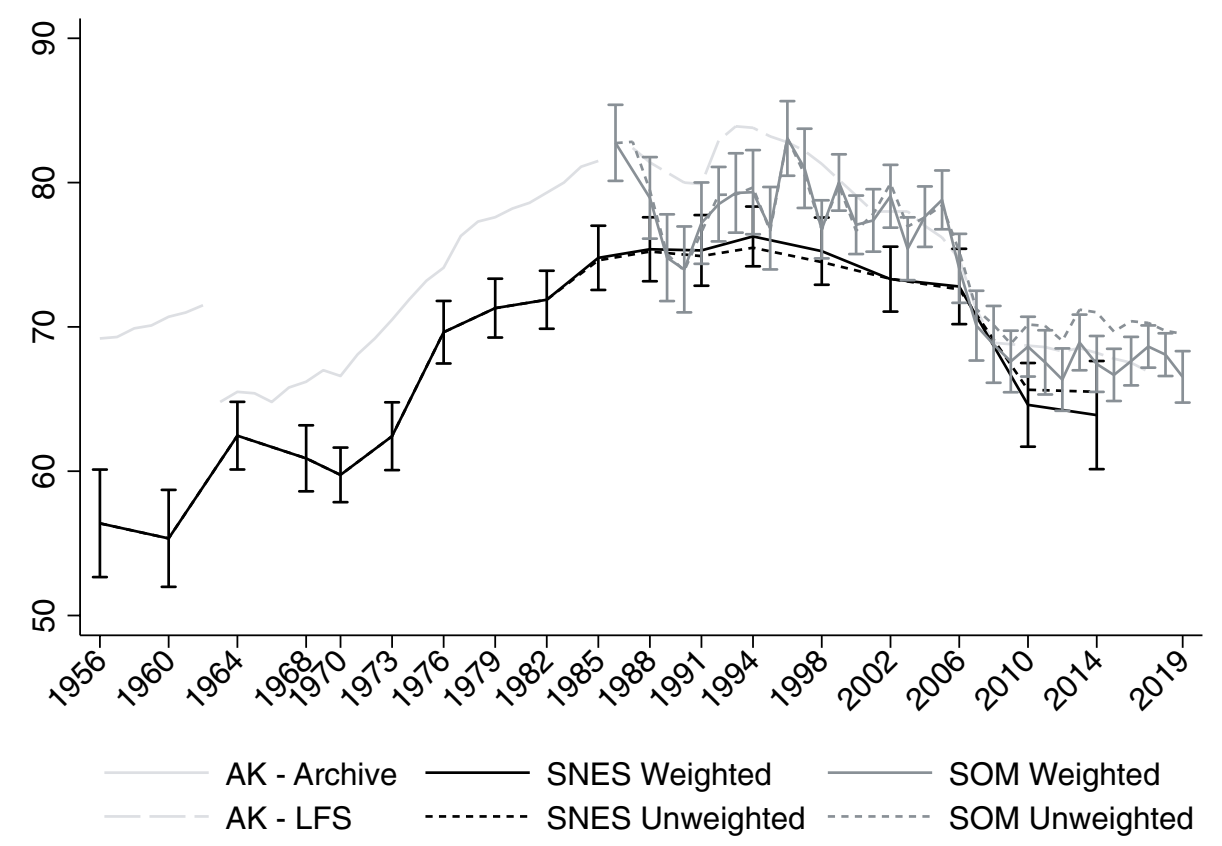

Notes: 95\% confidence intervals. The data includes only individuals active in the labor market. AK data are from Kjellberg (2019b, pp. 95-98). The break in the AK - Archive series in 1962-1963 is due to a change in how Statistics Sweden estimated the number of wage earners. The AK - LFS and the SOM series are estimated for respondents 16-64 years old. The SNES series are estimated for respondents aged 18-64 years. The weighted series are weighted on an interaction between education and age (see the methods section) from 1985 to 2019. The weighted SNES series is thus not weighted before 1985.

The SOM surveys follow the LFS numbers almost exactly, especially when the former is weighted. There is, however, an exception at the beginning of the 1990s, when the SOM surveys have a tendency towards a somewhat lower unionization rate. While these years involved great economic turmoil and mass unemployment in Sweden, it is not clear why this difference shows up in the data, since both sets of numbers are based on surveys. We interpret the closeness between the weighted SOM and LFS as justification for our weighting procedure as a meaningful correction for the non-response bias discussed above. In our empirical analyses below, we therefore use those weights whenever possible.

The SNES surveys also track the time series constructed by Kjellberg (2019b), although the point estimates are always 5-10 percentage points lower. The reason for this difference is also unclear. The most obvious difference between the sources is that the SNES surveys are based on face-to-face interviews, while the SOM surveys are postal, and LFS is based on telephone interviews. While survey research has shown that social desirability bias is more severe in face-to-face settings, it goes against our understanding that questions about union membership should be sensitive in that regard. The SNES 
surveys also deviate from Kjellberg's (2019b) reported data in that they show a much higher rise in the unionization rate between 1960 and 1964, and a corresponding decline between 1964 and 1968. Our best explanation for this is that the 1964 SNES survey oversampled union members.

There are possible concerns that the influx of migrants to Sweden may have affected unionization in ways that are not visible in these surveys. First, the SNES surveys exclude non-citizens (as it is a survey of voters). During the last decades, the number of migrants in Sweden that are not citizens has probably increased. The SNES surveys may thus have become less representative of this aspect of the Swedish labor market. Second, personal communication with analysts at the SOM Institute has revealed that the response rate is lower for people with foreign background, even under control for other socio-economic characteristics. To these concerns we respond as follows. (1) For SNES, we still see about the same changes between surveys as for SOM. (2) For SOM, the level of unionization there is still about the same as in the LFS. In 2015, Statistics Sweden published a report about the response rates in LFS, showing that it was not an especially serious problem with people with foreign background (Statistics Sweden 2015, p. 24). We also note that the gap in unionization rate between the older and the younger cohorts (see below) is somewhat larger in the later cohorts in the SOM survey, in spite of the SOM surveys including non-citizens in their population. We thus argue that while the unionization rate in later years may be slightly lower than our estimates, this should not influence the basic cohort patterns in any serious way, and the results should still be robust to this uncertainty.

Our conclusion from Figure 1 is that while there is reason for caution in some specific years, both the SNES and the SOM surveys are valid sources for analyses of broader trends in union membership in Sweden. Given that the SNES surveys constantly estimate a lower unionization rate, this bias is stable over the entire period and, as the overlapping confidence intervals show, the difference is often not statistically significant for single years. Thus, the SNES surveys are still useful for the study of change over time.

\section{Results}

\section{Lifespan curves for union membership}

Earlier research has debated whether union membership tends to follow a curvilinear pattern over the lifespan of a cohort, and thus should be modeled with a quadratic transformation (Blanchflower 2007; Schnabel \& Wagner 2012). In Sweden, the lifespan curves for union membership that we show in Figure 2 have a curvilinear character. However, it is also important to observe that the rise and decline of unionization in each cohort do not look very symmetrical, as suggested by the use of a squared age term (Blanchflower 2007). At least from the cohort born in the 1950s, the pattern shows a rather steep rise up until the age of 30, and then remains stable for 25-30 years followed by a much smaller decline around the age of 55-60.

This pattern calls into question the appropriateness of modelling the life-cycle development with a squared transformation. We would suggest that the steep rise 
among the young and the relatively small decline among the old make a negative inverse transformation $(-1 / \mathrm{x})$ more fitting to the actual development. This transformation captures well the correlation of a flatter rise with a lower plateau in membership that we see in the differences between the cohorts, especially between the cohorts born 19301970 and those thereafter.

Admittedly, as this transformation is monotonic, it does not capture old-age decline. However, old-age decline in union membership is arguably less relevant to model when the research question relates to generational change and replacement. In a recent paper, Blanchflower and Bryson (2021, pp. 12, 14, 19) show graphs where the curves look more symmetrical, but this is a consequence of an extension of the included lifespan. We would argue that the development beyond the normal retirement age is mostly a curiosity for analyses of union membership. However, it should be clearly stated that the correct choice of modeling strategy here is highly dependent on the purpose of the analysis. Nonetheless, we believe that the negative inverse transformation offers a more relevant alternative in most instances.

As a final comment on modeling choices, we note that Blanchflower's (2007, p. 16; see also Blanchflower \& Bryson 2021, p. 17) quadratic term produces estimates of when union membership peaks that are very different from our results. In his estimation, union membership peaks around the age of 46 in Sweden. In Figure 2, it is clear that the curves flatten earlier for all cohorts from the 1950s and onwards (although there is a later peak in the cohorts from the 1930s and 1940s). This earlier peak is also clear from the Finnish results of Böckerman and Uusitalo (2006, p. 297), where the rise in union membership also pans out around the age of 30 . Blanchflower (2007, pp. 18-21) also includes graphs with controls for cohorts that produce results that are more similar to ours and Böckerman and Uusitalo (2006). This difference, which may result from the use of different statistical methods, merits further investigation.

\section{Cohort differences}

In Figure 2, we plot the development in the unionization rate over the life cycle for each cohort from the 1920s to the 1990s, in the SNES and SOM surveys. The curves have been produced with locally weighted scatterplot smoothing (LOWESS) with a bandwidth of 0.8 . From these graphs, we make the following observations.

For the earliest cohorts (1920s-1940s), it may look as if there are some differences between SNES and SOM. In SOM, it appears that these cohorts were declining in unionization during the last part of their life cycle, from exceptionally high rates. However, we interpret this as an artefact of there being relatively few respondents born in the 1920s in the SOM data. In the SNES graph, on the other hand, we see that these earliest cohorts show an increasing unionization rate later in their life cycles. We find the latter observation more credible. We argue that this is a period effect of developments in the Swedish labor market in the late 1960s to the 1980s, which led to a large increase in unionization for white-collar groups, especially in the growing public sector and among women (for whom full-time work became much more common).

In both the SNES and SOM graphs, we see that unionization rises only during the first 10 years of the life cycle. Around the age of 30-35, the unionization rate reaches 
a peak, after which it is largely stable. In the earlier cohorts, this pattern is obscured by the period effects of the institutional changes in the 1970s, but it is very clear in the later cohorts, born after 1960. Together with earlier observations, such as by Böckerman and Uusitalo (2006), about the role of the pension system for unionization among older workers in Finland, we consider these results as further evidence that this pattern requires rather strong institutional changes and incentives to dislodge.

Figure 2 Age-by-cohort development in union membership.
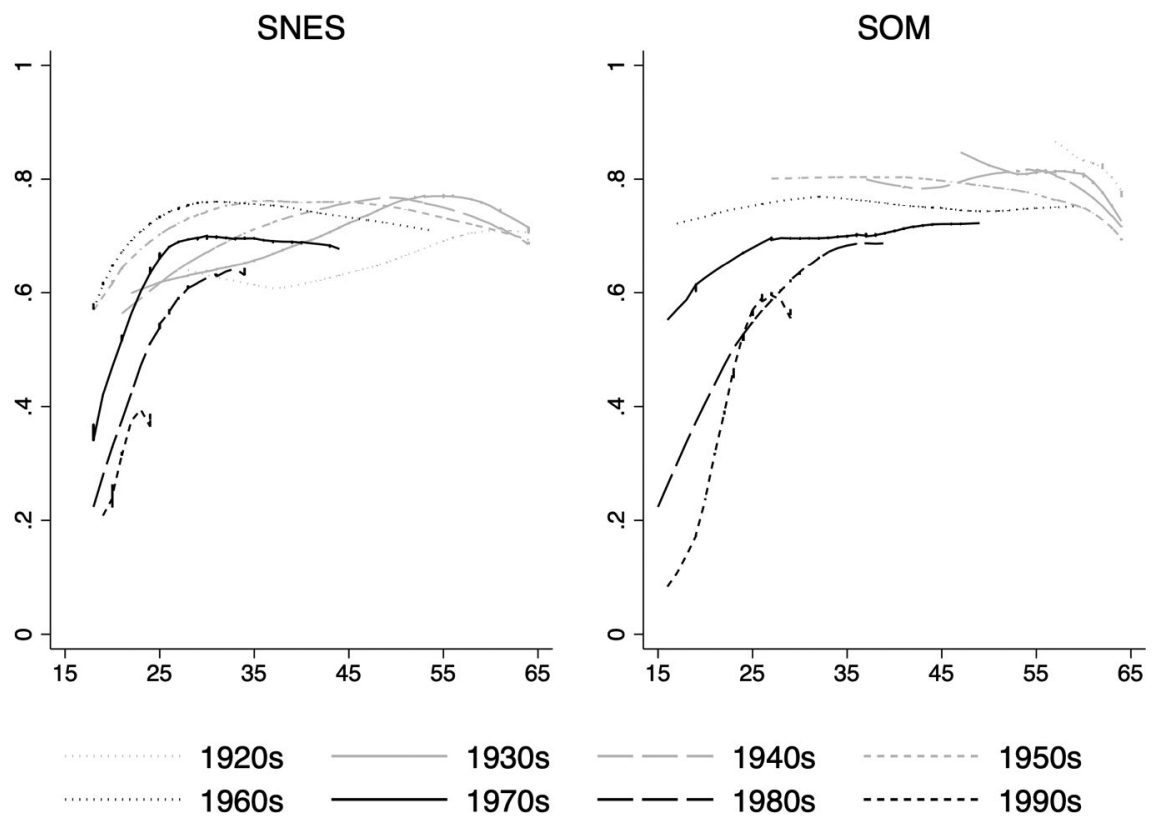

Comment: Plots are estimated with LOWESS (bandwidth 0.8). Sources: SNES 1956-20I4 and SOM I986-2019. Only respondents who are active in the labor market and aged 18-64 (SNES) or 16-64 (SOM) years have been included.

Finally, we make the obvious but nevertheless important observation that there are cohort differences in unionization in Sweden. In particular, the cohorts born after 1970 are organized to a lesser extent than those born before. It remains to be seen whether the very last cohorts (born in the 1980s and 1990s) continue this decline, or whether they eventually reach the same rate as people born in the 1970s. The small decline at the end of the curve for the 1990s cohort (in both the SNES and SOM graphs) is noise caused by having few cases of that age in the data. That said, the SNES and SOM graphs give somewhat different impressions regarding whether the 1980s cohort has kept up with that from the 1970s. In the SNES graph, it appears as if the 1980s cohort has a considerably lower unionization rate (by almost 10\%) than the 1970s cohort. In SOM, the 1980 s cohort still has a lower rate, although only marginally so. However, compared with the cohorts of the 1960s and the 1950s, the difference is still very clear. 


\section{Cohort differences and individualization}

Having documented cohort differences in union membership, we use the SOM surveys to assess the role of individualization and the hypothesis that these differences are related to value changes and more negative views of unions in the later cohorts.

In Table 2, we assess this hypothesis by estimating the cohort differences in an OLS regression model using cohort dummies for each cohort decade from the 1940s to the 1990s, and then controlling for different values. In our estimates, we have excluded respondents younger than 30 . At that age, the level of unionization has stabilized for all cohorts, and presumably also intergenerational differences in values. Including only the 'mature' period of each cohort avoids some more complex modeling choices that would have been involved in trying to include the varying slopes of the younger period of each cohort, and gives us a series of dummy coefficients that can be interpreted straightforwardly as differences between the cohort and the reference category in per cent. While modeling the slopes and explaining their variation are interesting tasks for further research, this approach works well for the purposes of the present study. Because the different value variables have been included in the SOM surveys somewhat irregularly, we provide a baseline estimation without the control variable for each value variable, and then compare that specific baseline to a model with the control included. To be able to fit the table on the page, we only include the coefficients of the cohort dummies. These estimates have been made without any other control variables.

All of these variables make at best a negligible impact on the coefficients of the cohort dummies. The largest difference is found when we control for An exciting life (Openness-to-change $(\mathrm{O})$ ), which reduces the coefficient for people born in the 1980s from -0.133 to -0.120 , and the coefficient for people born in the 1970 s from -0.078 to -0.067 . Thus, for the control variable where the relationships have the most overlap, it reduces the coefficient by at best $10-15 \%$, or $1-1.5$ percentage points. A similar small reduction (by 0.007 ) of the coefficient for the 1980s cohort can be found for National security (Conservation $(C)$ ), Self-realization (Self-enhancement (SE)), and Wealth (SE). However, most of the value variables make no difference whatsoever (the differences between the coefficients with and without controls are usually 0.001-0.003), and some of them-Family safety (Self-transcendence (ST)), True friendship (ST), and Trust in unions-even increase the size of the coefficients marginally. Our interpretation here is that there is very little overlap between the cohort differences in union membership and value changes.

Figures 3 and 4 provide some context to the results in Table 2. In Figure 3, we show the development of the prevalence of these values in each cohort. Here, the 5-point scale has been reduced to a dichotomous scale where $1-3$ is 0 and $4-5$ is 1 . This means that the graph shows the proportion of respondents in each cohort that positively endorses the value as important for them personally.

For Figure 3, we make the following observations. For most of these values, there are only very small to no differences between the cohorts. Some values-Freedom $(\mathrm{O})$, A world in peace (C), Justice (C), Family safety (ST), and True friendship (ST) are almost universally endorsed in all cohorts. Other values-National security (C), 


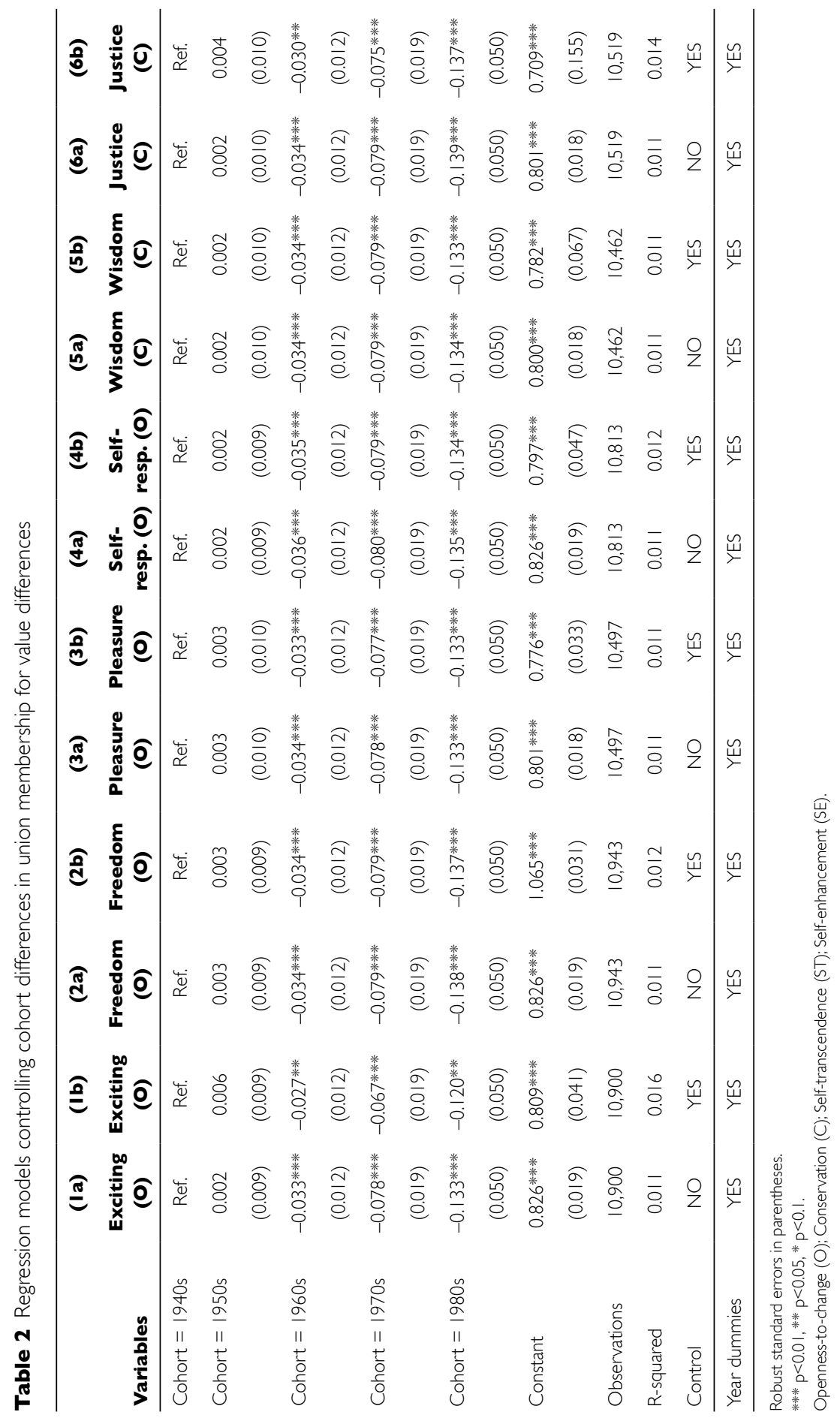




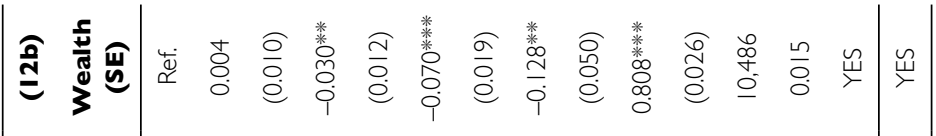

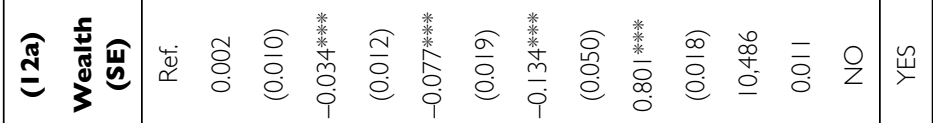

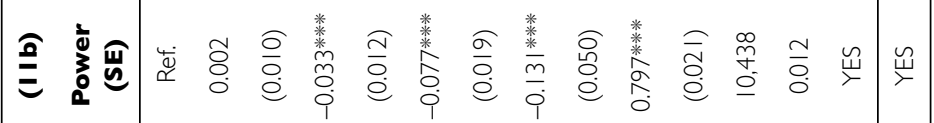

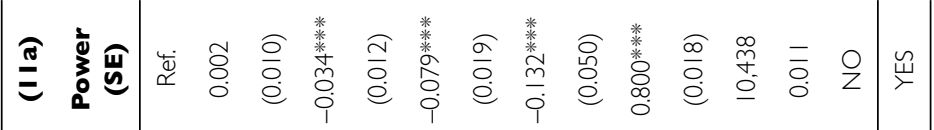

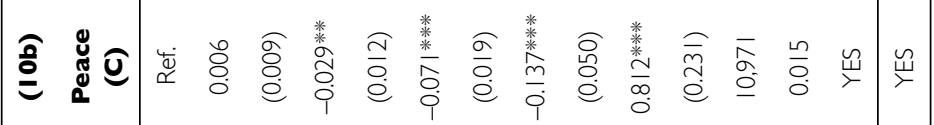

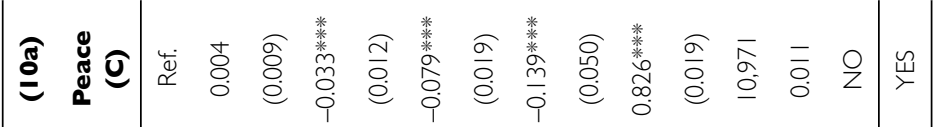

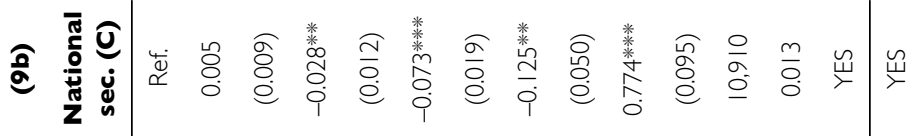

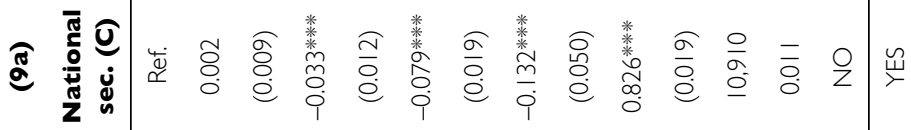

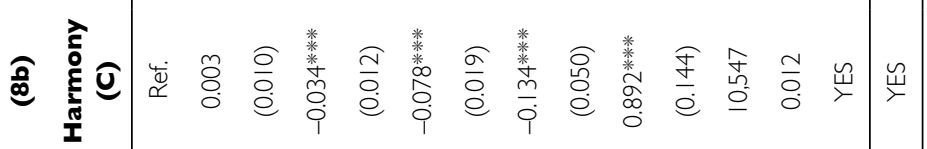

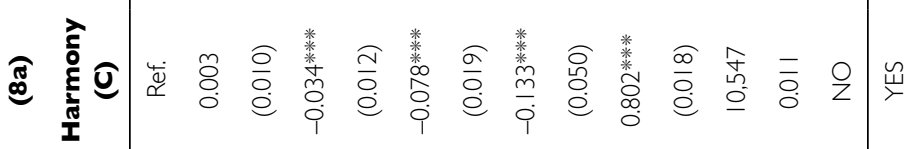

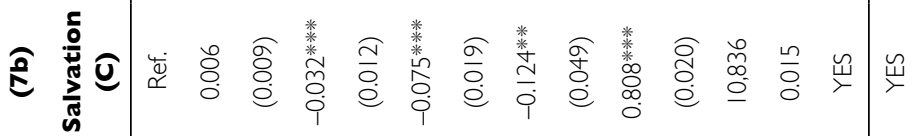

$$
\begin{aligned}
& \text { ๔ }
\end{aligned}
$$

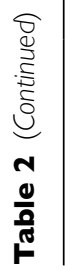

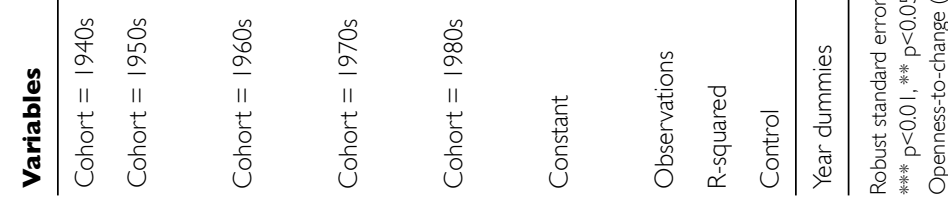




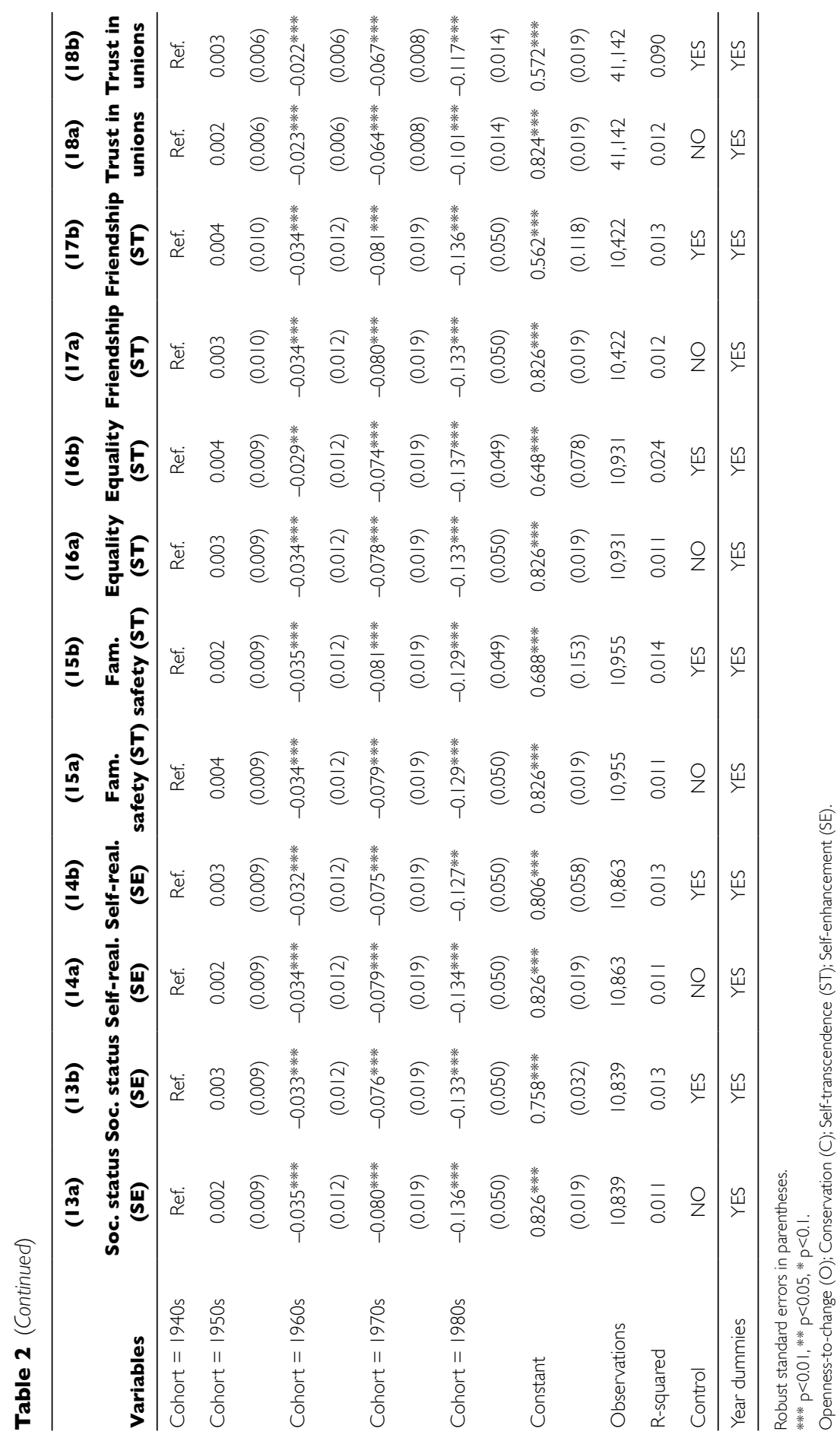



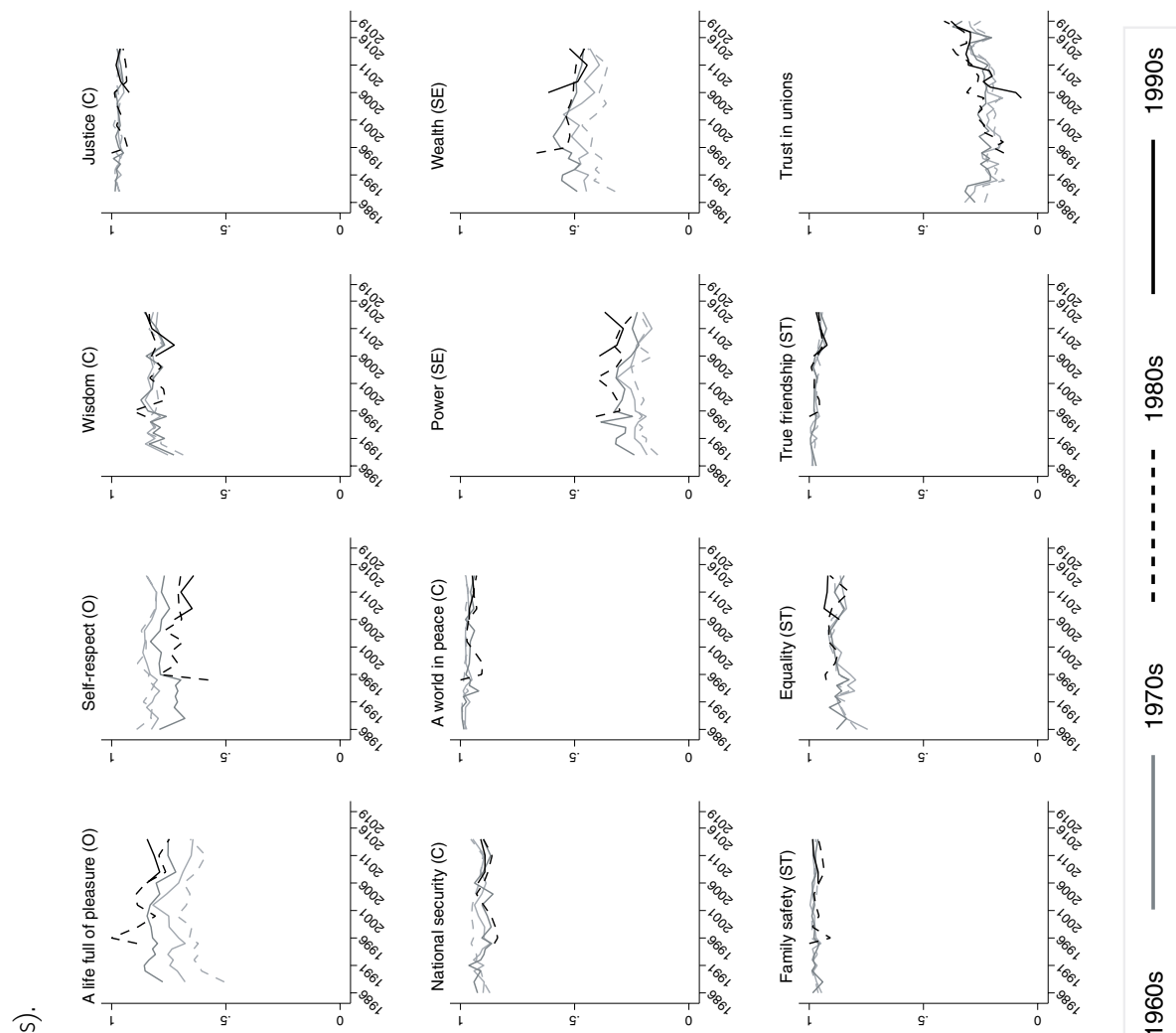

ஜ̊
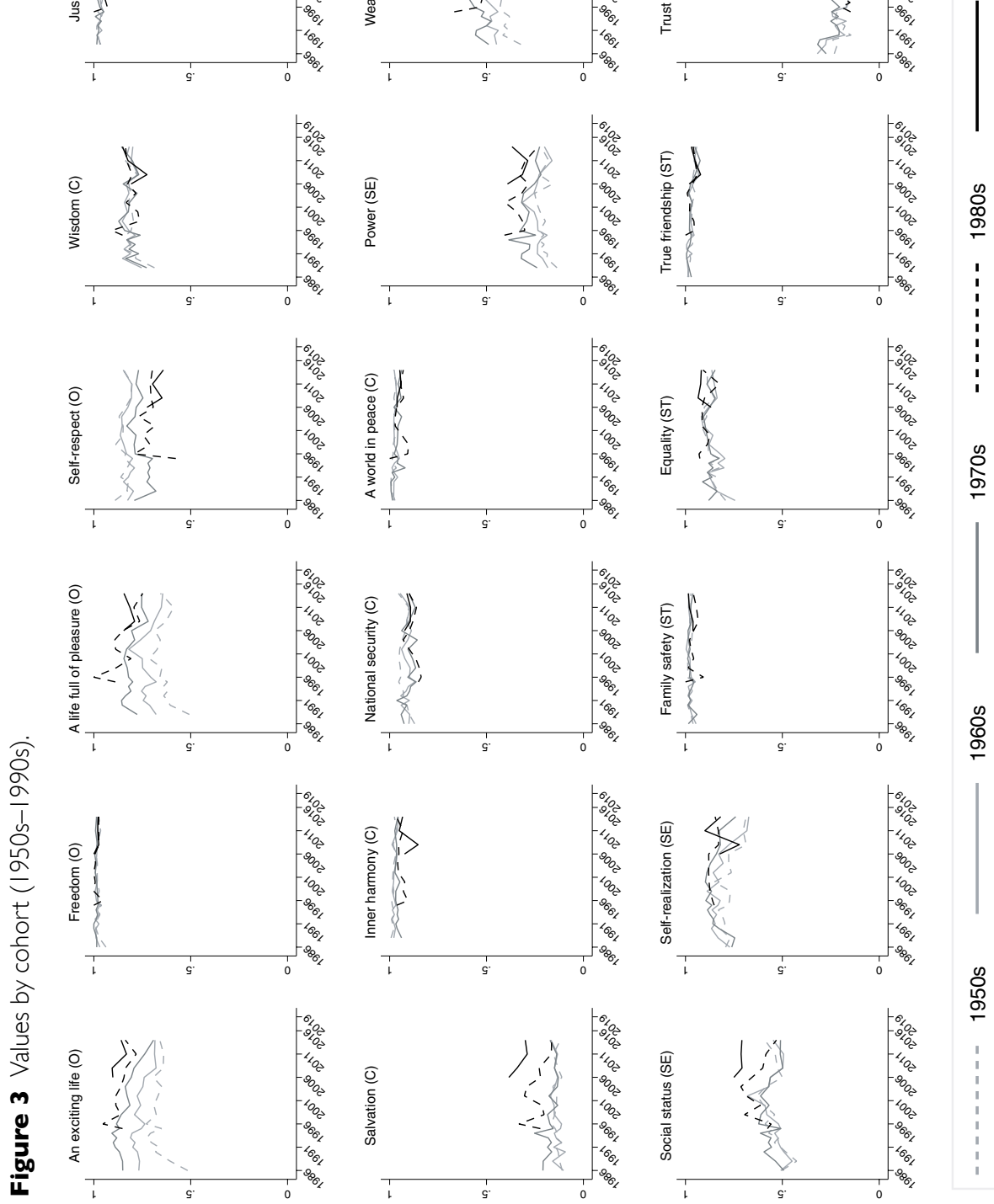

号

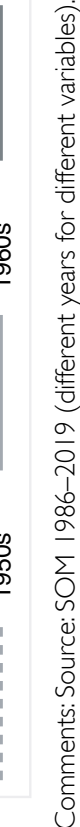


Figure 4 Relationship between union membership and values (predicted probabilities, 95\% Cl).
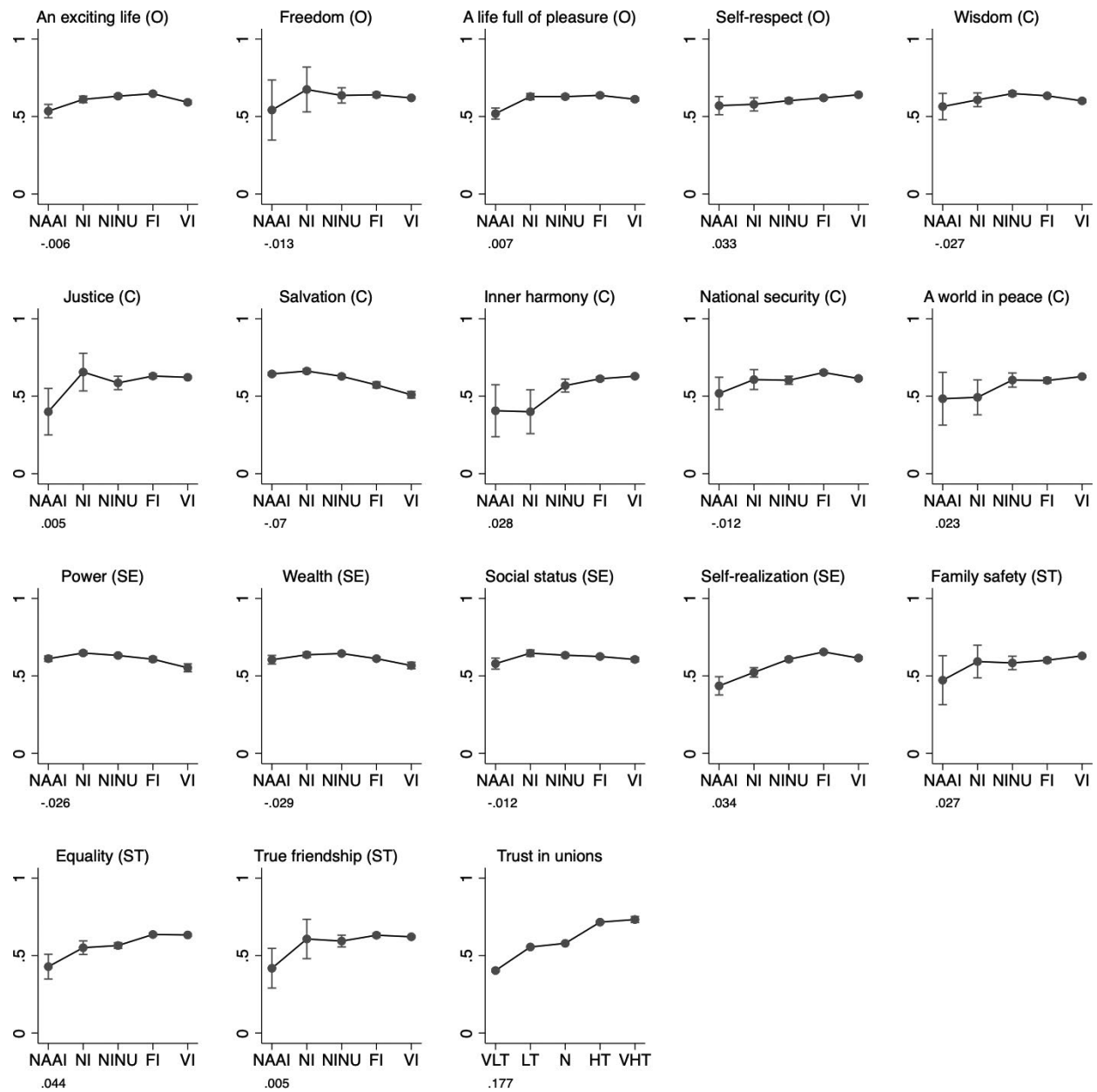

Comments: Source: SOM 1986-2019 (different years for different variables). The figure shows the global relationship across all years pooled together, including year dummies (robust standard errors). VLT = Very Low Trust, LT = Low Trust, $\mathrm{N}=$ Neither High nor Low Trust, $\mathrm{HT}=$ High Trust, $\mathrm{VHT}=$ Very High Trust, NAAI = Not At All Important, NI = Not Important, NINU = Neither Important Nor Unimportant, FI = Fairly Important, VI = Very Important. The number in the bottom left for each variable shows the global value of Spearman's rho.

Wisdom (C), and Equality (ST) - are not universally endorsed, but it is very difficult to see any generational trends. For Self-respect $(\mathrm{O})$, Salvation $(\mathrm{C})$, and Inner harmony $(\mathrm{C})$, we see some cohort differences, but in the opposite direction to what individualization theory would expect. Inner harmony $(\mathrm{C})$ seems to become somewhat less important in the younger cohorts, and Salvation (C) somewhat more important. A few values meet the expectations of the individualization hypothesis, namely the stronger tendency in the last cohorts to say that An exciting life $(\mathrm{O})$, A life full of 
pleasure (O), Self-realization (SE), Power (SE), Wealth (SE), and Social status (SE) are important. Indeed, these are also some of the values that are most directly related to the concept of individualization, as expressed through the higher-order value types of Openness-to-change and Self-enhancement. However, as shown in Table 2, not even these relatively large differences overlap very much on the individual level. In sum, while there are instances where later cohorts express more individualized attitudes, these attitudes have little to no relation to union membership. With regard to the leftright aspect of individualization, both Openness-to-change and Self-enhancement are equally represented among the values that have increased in the later cohorts, meaning that we find no tendency to either the left or the right in development of individualization. Finally, with regard to Trust in unions, if anything, there is more trust in unions in the younger cohorts, at least during the latter years, with a withincohort increase over time for people born in the 1980s and the 1990s.

Figure 4 shows the relationship between the value variables and union membership, across all surveys pooled together. This provides further insight into why the cohort differences do not overlap on the individual level. Of all of these values, only Salvation (C) is somewhat negatively related to probability of union membership. All the others are neutral, or slightly positive (the correlations are most often smaller than 0.1 , the highest Spearman's rho is 0.177 for Trust in unions). For the three values where we see the clearest cohort differences, An exciting life $(\mathrm{O})$ and A life full of pleasure $(\mathrm{O})$ have a neutral relationship $(-0.006$ and 0.007 , respectively), and Self-realization (SE) is only very slightly positive $(0.034)$.

Overall, our results show that there is very little overlap between the decline in union membership in later cohorts and the development in values over time. In many instances, the expected development has not occurred, and the relationship between the values and union membership is not even negative to begin with. These results for Sweden are also in line with the observation made by Kirmanoğlu and Başlevent (2012) that personal values seem to matter less in Ghent-system countries where union membership is more common and widespread.

\section{Conclusion}

In this article, we have presented three relevant findings for understanding the development of unionization in Sweden. First, there are cohort differences that, absent significant institutional changes, have put Sweden on the track of declining unionization for the coming years. Later cohorts have not reached the same level of union membership as earlier cohorts. Second, the typical pattern in Sweden over the last 50 years has been that unionization rises within each cohort until people are about 30 years old, it then plateaus for the next 25-30 years and declines slightly in the last years before retirement. However, in more recent cohorts (people born after 1970), the rise is not as steep and the plateau is lower. Third, these cohort differences only marginally overlap with generational differences in values. While we see some cases of increases in individualistic values among later cohorts, they do not explain cohort differences in union membership. Nor are the cohort differences in union membership related to a decline of trust in unions; if anything, later cohorts have more trust in unions than earlier cohorts. This is in line with the findings reported by Kjellberg (2020, p. 50) that young Swedes have a more

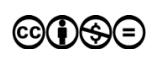


positive view of unions today compared with 20 years ago. Our results thus contradict the individualization hypothesis in two ways: (1) that more individualized attitudes are not related to lower union membership, implying that there is no inherent contradiction between individualism and union membership; and (2) the later cohorts that express more individualized attitudes have actually more trust in unions.

With regard to the actual explanation of the cohort differences found in our results, where later cohorts have more trust in unions but are also union members to a lesser degree, we suggest the need for a greater focus on structural and institutional factors. Jensen (2017) states that micro-oriented factors, in the form of political left-wing attitudes, increase the likelihood of joining a union in Sweden, although the results are less clear or missing with regard to the other Nordic countries. In this, he reaffirms the role of the particular structural and institutional settings in each country to understand the role of political attitudes for joining a trade union. The clear effect of institutional changes on union membership, as illustrated through the noticeable drop in Swedish union membership when the Ghent-style unemployment insurance fund system was changed in 2007 (Høgedahl \& Kongshøj 2017; Kjellberg 2020), shows the need for more research comparing institutional settings. Further institutional developments to investigate are the expansion of sectors of the economy that are more difficult to organize (a development that may have coincided with cohort-related recruiting patterns) and the expansion of atypical employment contracts. It should be emphasized, however, that these lines of research have to be constructed in a way that takes cohorts into account. For example, if structural transformations play a role in this, it also has to be shown that these transformations actually coincide with new cohorts entering the labor market and being recruited into these new types of positions.

In addition, more effort should be put into understanding the plateau pattern that we and others have observed on the micro level. If joining the labor market later in life in and of itself makes workers less prone to join a union, then longer formal education may be a problem for unions. Further research could benefit from considering how people's experience of the labor market influences their opinions of the pros and cons of joining a union. Furthermore, it should be noted that our study was conducted on a very aggregated level. While there seems to be some universality in the negative inverse cohort pattern that we describe, further research could also look into whether there is variation in the typical cohort development between social groups and labor market sectors.

Another finding that might be worth exploring further is the unexpected result that later cohorts have somewhat higher trust in unions in Sweden. In line with the suggestions above, it would be interesting to explore variation in the relationship between trust in unions (or perceptions of unions more generally) and membership, as a means to explicitly test hypotheses about the role of structural and institutional incentives vis-à-vis individual preferences.

Finally, our paper also contributes a methodological recommendation that the shape of the union membership and cohort pattern should be taken into greater account when choosing a transformation model. Our longer dataset suggests that a negative inverse transformation is the most apt for our case, and that the quadratic term used by Blanchflower (2007) and others may have led to misleading conclusions on both the shape and the peak of lifespan curves for union membership.

Our findings can also be translated into specific policy recommendations for unions. The results imply that Swedish unions do not have a general problem with 
their image among later cohorts. Combined with a briefer 'window of opportunity' for unions in Sweden to recruit younger people as union members, organizational development in the unions could well focus more substantively on how unions can help a new generation of wage earners in a transformed labor market, rather than on communication style and branding. With workers reaching a plateau of union membership at a relatively young age, unions need to better understand if the issue of recruitment of union members among those still in formal education is a way forward. Likewise, the rise of atypical employment and the increasing number of years workers spend in the labor market before finding a permanent position should be taken into consideration in strategic discussions about counteracting probationary employment and part-time work and making union membership more attractive among workers in atypical employment.

It is noteworthy that Böckerman and Uusitalo (2006) find rather similar results to ours for the Finnish cohorts concerning union membership development. This implies that Finnish unions could benefit from the same recommendations, and that further research in the other Nordic countries would be of interest to see if there are general Nordic cohort trends of union membership. However, the structural and institutional particularities (cf. Høgedahl \& Kongshøj 2017) of each country should also be considered to avoid simplified recommendations.

In the Introduction of this article, we mentioned that unions have typically been considered an important part of the Nordic labor market model, in order to facilitate shared prosperity. This analysis repeats earlier results that Swedish unionization is showing signs of erosion (although not due to individualization) and adds concerns that the cohort replacement that is currently in progress suggests that this is a long-term trend. Both our results and earlier research suggest that such patterns are fairly persistent and that it requires significant changes in structural or institutional incentives to modify them, as the current development includes both lower union density as well as fewer individuals in recent cohorts. The impact of the COVID-19 pandemic has once again brought to the fore the importance of security in the labor market with rising union membership as a result (Kjellberg 2021). Such an event could be an opportunity for the revitalization of the Nordic Model.

\section{References}

Beck, U. (1994). The debate on the individualization theory in today's sociology in Germany, Soziologie - Journal of the Deutsche Gesellschaft für Soziologie, Special Edition 3: 191-200.

Blanchflower, D. G. (2007). International patterns of union membership, British Journal of Industrial Relations 45(1): 1-28. doi: https://doi.org/10.1111/j.1467-8543.2007.00600.x.

Blanchflower, D. G. \& Bryson, A. (2021) Union membership peaks in midlife, British Journal of Industrial Relations, Early view. doi: https://doi.org/10.1111/bjir.12606.

Bryson, A., Gomez, R., Gunderson, M., \& Meltz, N. (2005). Youth-adult differences in the demand for unionization: Are American, British, and Canadian workers all that different? Journal of Labor Research 26(1): 155-167.

Budd, J. W. (2010). When do US workers first experience unionization? Implications for revitalizing the labor movement, Industrial Relations: A Journal of Economy and Society 49(2): 209-225. doi: https://doi.org/10.1111/j.1468-232X.2009.00596.x. 
Böckerman, P., \& Uusitalo, R. (2006). Erosion of the Ghent system and union membership decline: Lessons from Finland, British Journal of Industrial Relations 44(2): 283-303. doi: https://doi.org/10.1111/j.1467-8543.2006.00498.x.

Ebbinghaus, B., Göbel, C., \& Koos, S. (2011). Social capital, ‘Ghent’and workplace contexts matter: Comparing union membership in Europe, European Journal of Industrial Relations 17(2): 107-124. doi: https://doi.org/10.1177/0959680111400894.

Falk, E. (2019). Den nationella SOM-undersökningen 2019 [The national SOM survey 2019], 465-473 in Andersson, U., Carlander, A. \& Öhberg, P. (eds) Regntunga skyar [Rainy clouds]. SOM Anthology 76. SOM Institute: University of Gothenburg.

Gomez, R., Gunderson, M., \& Meltz, N. (2002). Comparing youth and adult desire for unionization in Canada, British Journal of Industrial Relations 40(3): 542-519. doi: https:// doi.org/10.1111/1467-8543.00245.

Høgedahl, L., \& Kongshøj, K. (2017). New trajectories of unionization in the Nordic Ghent countries: Changing labor market and welfare institutions, European Journal of Industrial Relations 23(4): 365-380. doi: https://doi.org/10.1177/0959680116687666.

Jensen, C. S. (2017). Political attitudes and trade union membership in the Nordic countries, European Journal of Industrial Relations 23(4): 381-395. doi: https://doi.org/10.1177/ 0959680117708372.

Inglehart, R. (1997). Modernization and Postmodernization: Cultural, Economic, and Political Change in 43 Societies, Princeton: Princeton University Press.

Kilburn, H. W. (2009). Personal values and public opinion, Social Science Quarterly 90(4): 868-885. doi: https://doi.org/10.1111/j.1540-6237.2009.00667.x.

Kirmanoğlu, H., \& Başlevent, C. (2012). Using basic personal values to test theories of union membership, Socio-Economic Review 10(4): 683-703. doi: https://doi.org/10.1093/ser/ mwr020.

Kjellberg, A. (2021). Den svenska modellen 2020: pandemi och nytt huvudavtal [The Swedish Model 2020: Pandemic and a New Main Agreement]. Arena Idé.

Kjellberg, A. (2020). Den svenska modellen i en oviss tid: Fack, arbetsgivare och kollektivavtal på en föränderlig arbetsmarknad. [The Swedish Model in an Uncertain Time: Trade Unions, Employers and Collective Agreements in a Changing Labor Market]. Arena Idé.

Kjellberg, A. (2019a). Sweden: Collective bargaining under the industry norm. In T. Müller, K. Vandaele, \& J. Waddington (eds), Collective bargaining in Europe: Towards an endgame (Vol. 3, pp. 583-603). ETUI (EuropeanTrade Union Institute), Bruxelles.

Kjellberg, A. (2019b). Kollektivavtalens täckningsgrad samt organisationsgraden hos arbetsgivarförbund och fackförbund [The degree of collective bargaining coverage and the level of organization of employer associations and trade unions]. Studies in Social Policy, Industrial Relations, Working Life and Mobility 2018(1). Department of Sociology: Lund University.

Markstedt, E. (2014). Representativitet och viktning - Riks-SOM som spegel av det svenska samhället 1986-2013 [Representativeness and weighting - Riks-SOM as a mirror of Swedish society 1986-2013]. SOM Report 2014:10. SOM Institute: University of Gothenburg.

Oleskog Tryggvason, P., \& Hedberg, P. (2015). Swedish national election studies program method report: Super election edition. Swedish National Election Studies Working paper series 2015, 1 .

Palm, J. (2017). There is power in a union: Trade union organization, union membership and union activity in Sweden (Doctoral dissertation, Department of Sociology, Stockholm University).

Rasmussen, M. \& Pontusson J. (2018). Working-class strength by institutional design? Unionization, partisan politics, and unemployment insurance systems, 1870 to 2010, Comparative Political Studies 51(6): 793-828. doi: https://doi.org/10.1177/0010414017710269. 
Schnabel, C. (2013). Union membership and density: Some (not so) stylized facts and challenges, European Journal of Industrial Relations 19(3): 255-272. doi: https://doi.org/10.1177/ 0959680113493373.

Schnabel, C., \& Wagner, J. (2007). Union density and determinants of union membership in 18 EU countries: Evidence from micro data, 2002/03 1, Industrial Relations Journal 38(1): 5-32. doi: https://doi.org/10.1111/j.1468-2338.2007.00433.x.

Schnabel, C., \& Wagner, J. (2008). The aging of the unions in West Germany, 1980-2006, Working Paper Series in Economics, No. 93, Leuphana Universität Lüneburg, Institut für Volkswirtschaftslehre, Lüneburg. https://www.econstor.eu/handle/10419/28211.

Schnabel, C., \& Wagner, J. (2012). With or without U? Testing the hypothesis of an inverted U-shaped union membership-age relationship, Contemporary Economics 6(4): 28-34.

Statistics Sweden (2015) Background facts 2015: 4, Patterns of non-response in the Swedish LFS.

Visser, J. (2002). Why fewer workers join unions in Europe: A social custom explanation of membership trends, British Journal of Industrial Relations 40(3): 403-430. doi: https:// doi.org/10.1111/1467-8543.00241.

Visser, J. (2019). Trade unions in the balance, Geneva: International Labor Organization's Bureau for Workers' Activities (ACTRAV).

\section{Notes}

${ }^{1}$ Rasmussen and Pontusson (2018), however, argue that state subsidization and benefit generosity through the Ghent system, rather than the system itself, improve union density.

${ }^{2} \mathrm{~A}$ peak in Finnish union density is reported around 55 years of age, most likely as a result of union membership being beneficial in early retirement schemes that one could apply for at this age (Böckerman \& Uusitalo 2006). Similar schemes do not exist in Sweden.

${ }^{3}$ Visser's argument is that flexible workers have fewer stable contacts with fellow workers and are mainly employed in sectors where there are few union members, such as retail, cleaning, and hotel and restaurants. They are thus less likely to meet union recruiters or see the benefits of union services, and face little reputation loss for not joining (Visser 2002). 